\title{
THE EFFECT OF SPONTANEOUS AND ARTIFICIALLY INDUCED FEVER ON LIVER FUNCTION
}

\author{
By MYERS H. HICKS, HOWARD P. HOLT, JOHN L. GUERRANT, \\ AND BYRD S. LEAVELL
}

(From the Department of Intermal Medicine, University of Virginia Medical School, University of Virginia Hospital, Charlottesville, Va.)

(Received for publication April 1, 1948)

Abnormal liver function has been reported in malaria (1-11), and in infectious mononucleosis (12), and its occurrence has been mentioned in pneumonia (13). Wade and Richmann (14) considered the possible influence of non-specific fever on the cephalin-cholesterol flocculation test, and Machella (15) has reported bromsulfalein retention during fever following foreign protein injection. Bragdon (16) recently reported a fatal case of post hypertherm hepatitis and others (17-25) have reported various degrees of liver damage associated with hyperpyrexia.

While on duty with the Eighth Evacuation Hospital of the Fifth Army in Italy during the winter of 1944-45 we had the opportunity to observe the behavior of several liver function tests in various disorders. Those observations indicated that abnormal results occurred frequently in conditions other than infectious hepatitis and led us to suspect that fever exerted an important influence on the rate of bromsulfalein clearance. This suggested the importance of studying the effect of artificially induced fever on liver function. Such a study has been completed on patients on the wards of the University of Virginia Hospital. The observations made on Army personnel with various diseases and those made on patients with induced fever are reported in this communication.

\section{METHODS}

In the subjects with various diseases the choice of tests was limited by the circumstances under which the studies were performed. The following procedures were employed :

1. The bromsulfalein liver function test as modified by Mateer et al. (26) in which $5 \mathrm{mgm}$. of dye per kilogram of body weight are given intravenously and the percentage retention determined in a single blood sample after 45 minutes.

2. Cephalin-cholesterol flocculation test: method of Hanger (27). Normal serum was always used as a control.
In the individuals in whom fever was induced by artificial means the following observations were made in each subject:

1. The bromsulfalein clearance (26);

2. Cephalin-cholesterol flocculation of Hanger (27);

3. Prothrombin time; Quick (28) ;

4. Total plasma protein by the copper sulfate method (29) ;

5. Icterus index using potassium dichromate standards;

6. Plasma bilirubin level (30);

7. Hematocrit, erythrocyte count, and hemoglobin determination (31);

8. Repeated measurements of the pulse, blood pressure, skin temperature and rectal temperature.

\section{MATERIAL}

The patients with clinical diseases were divided into four groups:

Group I: Acute infectious hepatitis with jaundice. One hundred and twenty patients in this group had overt jaundice at the time of admission to the hospital. The average duration of symptoms before admission was 8.0 days.

Group II: Tertian malaria. This group was composed of 100 patients treated in the hospital for malaria. In each instance the diagnosis was established by the finding of plasmodium vivax in the peripheral blood.

Group III: Primary atypical pneumonia. There were 100 patients in this group. In each instance the history, clinical course, leukocyte count, and chest roentgenogram were consistent with the diagnosis. The average duration of fever was 9.3 days and the average period of hospitalization of 50 unselected cases was 23.0 days. (It has been shown that " $Q$ " fever was prevalent in the region at the time this study was carried out, and it is possible that some cases of this disease were included in Group III.)

Group IV: Miscellaneous conditions. This group consisted of 51 patients who gave a negative history of jaundice, malaria, infectious mononucleosis, and pneumonia, and had no evidence of these diseases during the period of observation. Of these, 37 were patients without fever who were diagnosed anxiety state, scabies, sprains (back, knee, ankle), acute gonorrheal urethritis, and epididymitis, acute and recurrent. The remaining 14 patients had fever due to acute tonsillitis, lobar pneumonia, acute epididymitis, acute appendicitis, cellulitis of jaw, wounds of the extremities, acute gastroenteritis and 
bacillary dysentery. Fevers of unknown origin were not included.

In the study of the effect of artificially induced fever, 12 white subjects of both sexes, ranging in age from 16 to 50 , were used. These patients with syphilis, arthritis, chorea, or psychoneurosis were subjected to 26 bouts of fever induced by the intravenous injection of killed typhoid organisms. These patients were not denied water and were given salt in the form of tablets at regular intervals during the febrile period. Liver function tests were performed before injection of the foreign protein and were repeated three to four hours later when fever had been present for about two hours. In nine individuals liver function tests were repeated within 24 hours after fever had subsided. Sample observations are shown in Figure 1. The control studies were performed on white and colored subjects of both sexes, ranging in age from 16 to 56 .

\section{RESULTS}

\section{Cephalin-cholesterol flocculation test}

The percentage of patients in Groups II, III and IV showing positive flocculation tests is
TABLE I

Results of cephalin-cholesterol flocculation tests in patients with illnesses other than infectious hepatitis

\begin{tabular}{|c|c|c|c|c|c|}
\hline \multirow{2}{*}{ Groups } & \multirow{2}{*}{$\begin{array}{l}\text { Max. oral } \\
\text { temperature } \\
\text { day of test }\end{array}$} & \multirow{2}{*}{$\begin{array}{l}\text { Number } \\
\text { of tests }\end{array}$} & \multicolumn{3}{|c|}{$\begin{array}{l}\text { Flocculation reading at } \\
24 \text { hours }\end{array}$} \\
\hline & & & ++++ & ++ & $\stackrel{+}{0}$ \\
\hline II & $\begin{array}{c}{ }^{\circ} F . \\
103 \text { or more } \\
99^{2}-102^{8} \\
99 \text { or less }\end{array}$ & $\begin{array}{r}10 \\
8 \\
89\end{array}$ & $\begin{array}{r}\text { per cent } \\
80.0 \\
100.0 \\
82.0\end{array}$ & $\begin{array}{c}\text { per cent } \\
10.0 \\
0.0 \\
11.0\end{array}$ & $\begin{array}{c}\text { per cent } \\
10.0 \\
0.0 \\
7.0\end{array}$ \\
\hline III & $\begin{array}{l}103 \text { or more } \\
99^{2}-102^{8} \\
99 \text { or less }\end{array}$ & $\begin{array}{l}44 \\
39 \\
71\end{array}$ & $\begin{array}{l}27.0 \\
20.0 \\
52.0\end{array}$ & $\begin{array}{l}11.0 \\
18.0 \\
11.0\end{array}$ & $\begin{array}{l}62.0 \\
62.0 \\
37.0\end{array}$ \\
\hline IV & $\begin{array}{l}99^{2} \text { or more } \\
99 \text { or less }\end{array}$ & $\begin{array}{l}14 \\
37\end{array}$ & $\begin{array}{r}28.5 \\
5.9\end{array}$ & $\begin{array}{r}28.5 \\
8.1\end{array}$ & $\begin{array}{l}43.0 \\
86.0\end{array}$ \\
\hline
\end{tabular}

shown in Table I. No correlation with the amount of fever is apparent. An unexplained but interesting observation is the higher incidence of abnormal cephalin-cholesterol flocculation in the

SUBJECT 3

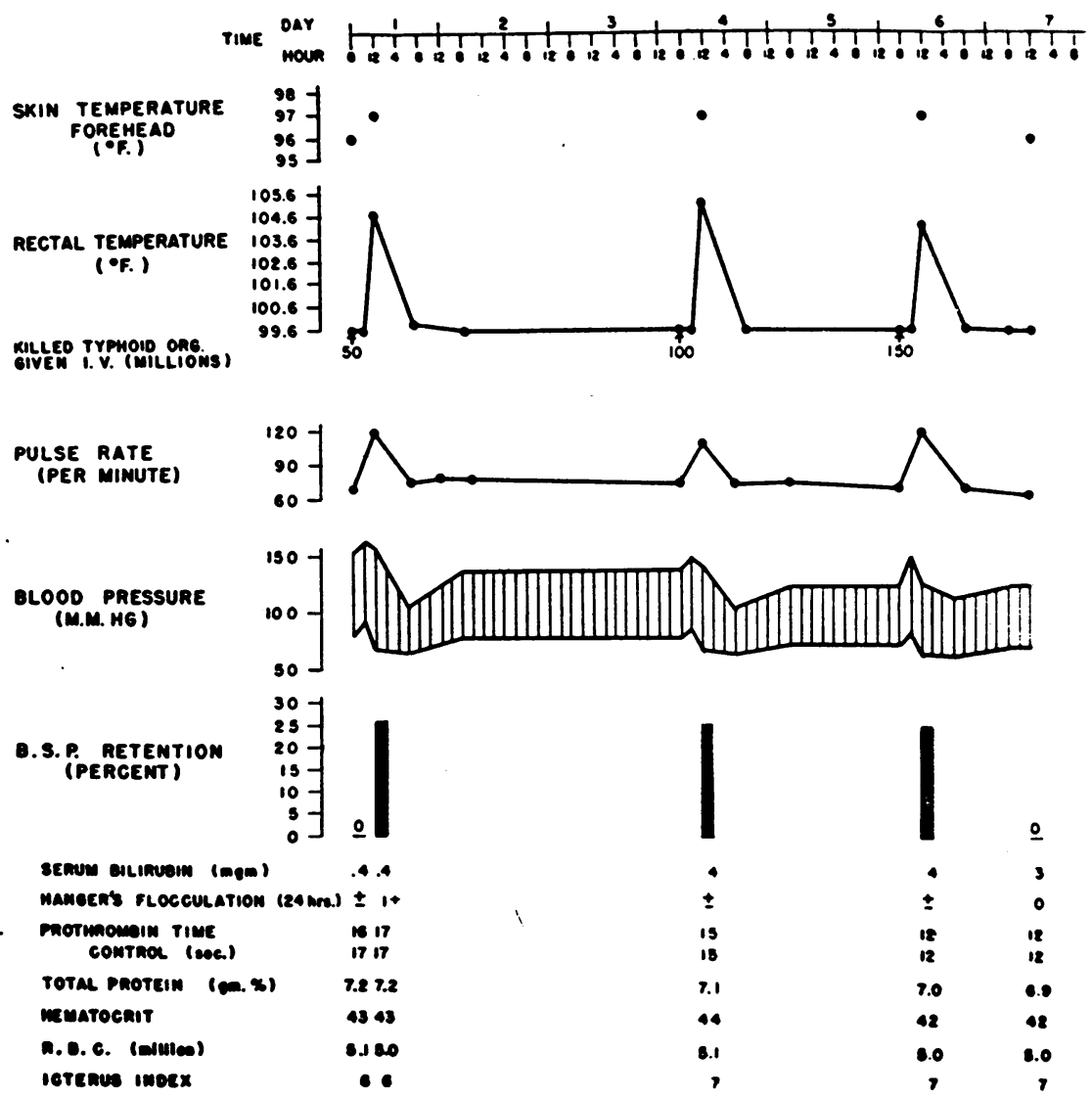

Fig. 1. Sample Chart Illustrating Investigations on Each Subject 
MYERS H. HICKS, HOWARD P. HOLT, JOHN L. GUERRANT, AND BYRD S. LEAVELL

TABLE II

Results of cephalin-cholesterol flocculation test in atypical pneumonia and infectious hepatitis

\begin{tabular}{|c|c|c|c|c|c|c|c|c|}
\hline \multirow{3}{*}{$\begin{array}{l}\text { Week of } \\
\text { disease }\end{array}$} & \multicolumn{4}{|c|}{ Atypical pneumonia } & \multicolumn{4}{|c|}{ Infectious hepatitis } \\
\hline & \multirow{2}{*}{$\begin{array}{c}\text { Number of } \\
\text { tests }\end{array}$} & \multicolumn{3}{|c|}{ Flocculation reading 24 hours } & \multirow{2}{*}{$\begin{array}{c}\text { Number of } \\
\text { tests }\end{array}$} & \multicolumn{3}{|c|}{ Flocculation reading 24 hours } \\
\hline & & $\underset{+++}{++}$ & ++ & $\stackrel{+}{0}$ & & $\underset{+++}{++}$ & ++ & \pm \\
\hline $\begin{array}{l}1 \\
2 \\
3 \\
4\end{array}$ & $\begin{array}{l}69 \\
77 \\
58 \\
30\end{array}$ & $\begin{array}{c}\text { per cent } \\
24.4 \\
27.3 \\
58.0 \\
76.0\end{array}$ & $\begin{array}{c}\text { per cent } \\
10.0 \\
18.1 \\
12.0 \\
7.0\end{array}$ & $\begin{array}{c}\text { per cent } \\
65.6 \\
54.6 \\
30.0 \\
17.0\end{array}$ & $\begin{array}{l}53 \\
71 \\
12\end{array}$ & $\begin{array}{c}\text { per cent } \\
96.2 \\
91.0 \\
75.0\end{array}$ & $\begin{array}{c}\text { per cent } \\
3.8 \\
7.5 \\
25.0\end{array}$ & $\begin{array}{c}\text { per cent } \\
0.0 \\
1.5 \\
0.0\end{array}$ \\
\hline
\end{tabular}

post-febrile period in the atypical pneumonia group. Table II compares the percentage of positive tests in atypical pneumonia (Group III) and acute hepatitis (Group I) with reference to the weeks after onset of the disease. It is apparent that the incidence of positive tests increases in the pneumonia group with the lapse of time while the hepatitis group shows no such change. In Figure 2 are shown the results of the cephalincholesterol flocculation tests with reference to day of disease in three patients with atypical pneumonia. In a majority of these patients, we were unable to determine the length of time that the flocculation reaction persisted. In 19 patients the test was performed between 30 and 50 days after onset and a 3 plus reaction at 24 hours occurred in 14 patients, a 2 plus reaction in one.

\section{Bromsulfalein test}

Bromsulfalein tests were not performed in patients with jaundice (Group I). The relationship between the amount of fever in the patients in Groups II, III and IV and the percentage of these patients showing an abnormal bromsulfalein retention is presented in Table III. Abnormal dye retention occurred much oftener in each group when fever was present. No patients with malaria showed any dye retention when the test was performed two days or more after the termination of fever. Figure 3 illustrates the relationship of fever and bromsulfalein retention in an individual with atypical pneumonia.

Of the tests related to liver function, only the bromsulfalein test showed significant variation in subjects with fever induced by artificial means.

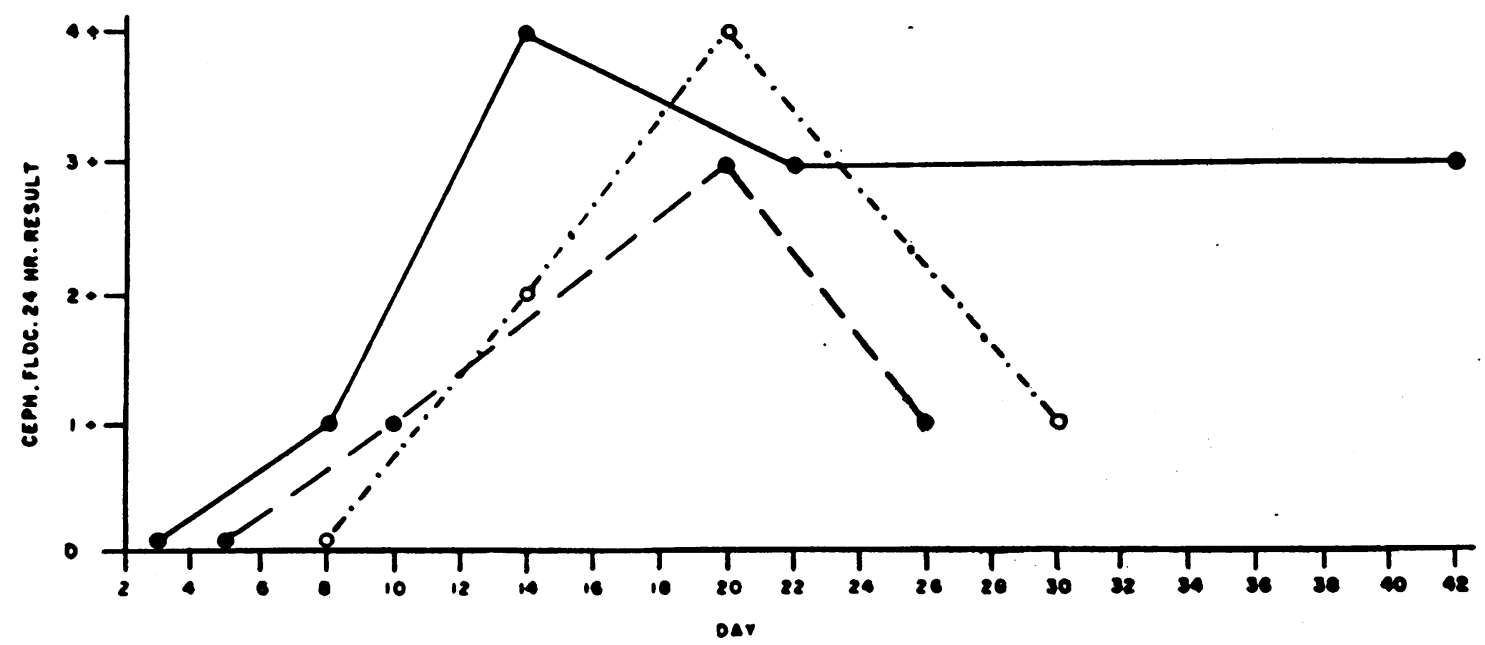

Fig. 2. Cephalin-Cholesterol Flocculation Tests in Three Patients at Different Times after Onset of Atypical Pneumonia 


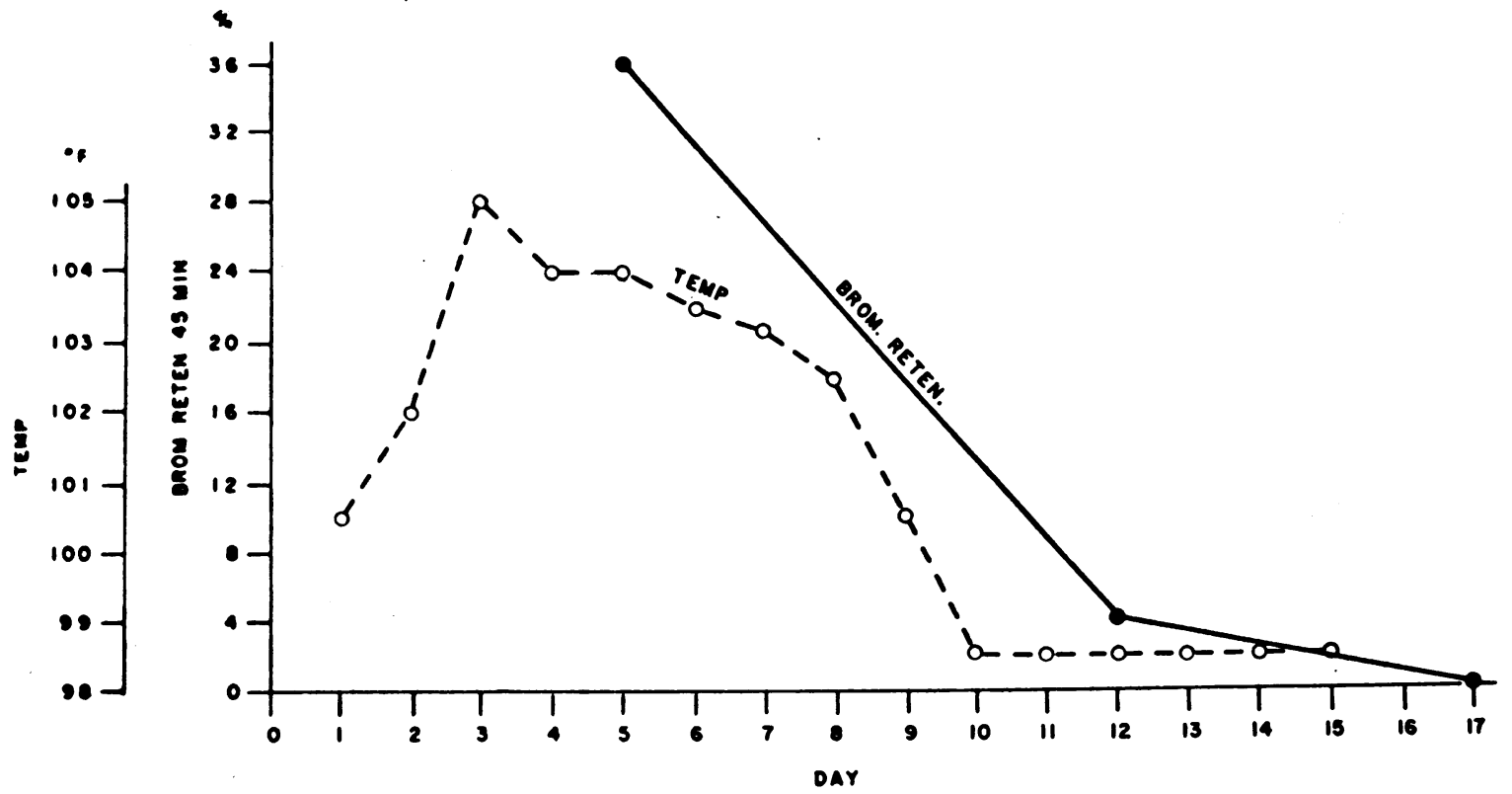

Fig. 3. Bromsulfalein Tests and Temperature Curve in a Patient with Atypical Pneumonia

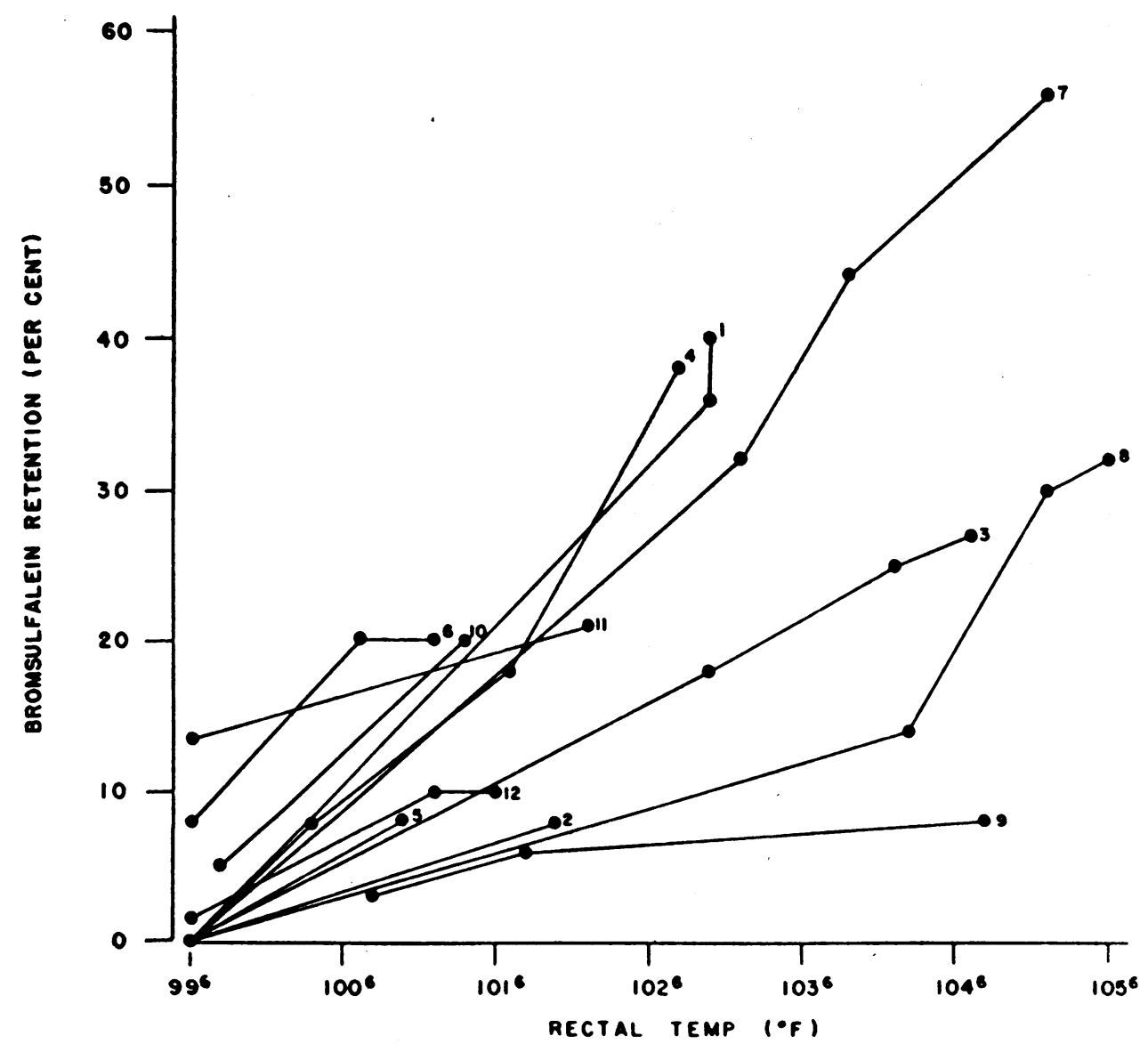

Fig. 4. Bromsulfalein Tests in 12 Patients with Fever Induced by Injection of Foreign Protein 
TABLE III

Results of bromsulfalein tests in patients with illnesses other than infectious hepatitis

\begin{tabular}{|c|c|c|c|c|c|}
\hline \multirow{2}{*}{ Groups } & \multirow{2}{*}{$\begin{array}{l}\text { Max. oral } \\
\text { temperature } \\
\text { day of test }\end{array}$} & \multirow{2}{*}{$\begin{array}{c}\text { Number } \\
\text { of tests }\end{array}$} & \multicolumn{3}{|c|}{$\begin{array}{l}\text { Bromsulf, retention at } \\
45 \text { minutes }\end{array}$} \\
\hline & & & $\begin{array}{l}\text { Over } 8 \\
\text { per cent }\end{array}$ & $\begin{array}{c}4 \text { to } 8 \\
\text { per cent }\end{array}$ & $\begin{array}{l}\text { Under } 4 \\
\text { per cent }\end{array}$ \\
\hline II & $\begin{array}{c}{ }^{\circ} F . \\
103 \text { or more } \\
99^{2}-102^{8} \\
99 \text { or less }\end{array}$ & $\begin{array}{l}19 \\
14 \\
89\end{array}$ & $\begin{array}{c}\text { per cent } \\
48.0 \\
0.0 \\
2.5\end{array}$ & $\begin{array}{c}\text { per cent } \\
21.0 \\
21.0 \\
4.5\end{array}$ & $\begin{array}{c}\text { per cent } \\
31.0 \\
79.0 \\
93.0\end{array}$ \\
\hline III & $\begin{array}{c}103 \text { or more } \\
99^{2}-102^{8} \\
99 \text { or less }\end{array}$ & $\begin{array}{l}52 \\
49 \\
51\end{array}$ & $\begin{array}{r}33.0 \\
22.0 \\
4.0\end{array}$ & $\begin{array}{r}19.0 \\
27.0 \\
8.0\end{array}$ & $\begin{array}{l}48.0 \\
51.0 \\
88.0\end{array}$ \\
\hline IV & $\begin{array}{l}99^{2} \text { or more } \\
99 \text { or less }\end{array}$ & $\begin{array}{l}20 \\
36\end{array}$ & $\begin{array}{r}25.0 \\
0.0\end{array}$ & $\begin{array}{l}0.0 \\
5.5\end{array}$ & $\begin{array}{l}75.0 \\
94.5\end{array}$ \\
\hline
\end{tabular}

In each subject the percentage of dye retention was greater during fever than in the control period (Figure 4). Although there was considerable quantitative variation in different individuals, each subject showed increasing dye retention with increasing temperature. A temperature rise of three degrees or more appeared especially significant. In 13 instances when temperature was more than $102.6^{\circ}$ rectally the average bromsulfalein reten- tion was $30.5 \%$, while in 13 tests performed when the temperature ranged from $100.6^{\circ}$ and $102.6^{\circ}$ rectally, the average dye retention was only $11.1 \%$.

In nine individuals liver function tests were repeated within 24 hours after fever had subsided. In four, the dye retention equaled control levels. In five, retention was above the control value but substantially below the value observed during fever.

To clarify these observations, three groups of individuals were used in various control studies:

1. In ten subjects who had various disorders associated with different degrees of bromsulfalein retention, bromsulfalein tests were performed and repeated after an interval of three hours. The results are shown in Table IV. In each individual the result of the second test agrees with that of the initial test. This procedure was done to determine if repeated injection of the dye at three-hour intervals caused any increase in dye retention.

2. In four subjects, five bouts of fever were induced by the application of external heat. These results, shown in Figure 5, are similar to those obtained with foreign protein in that increased

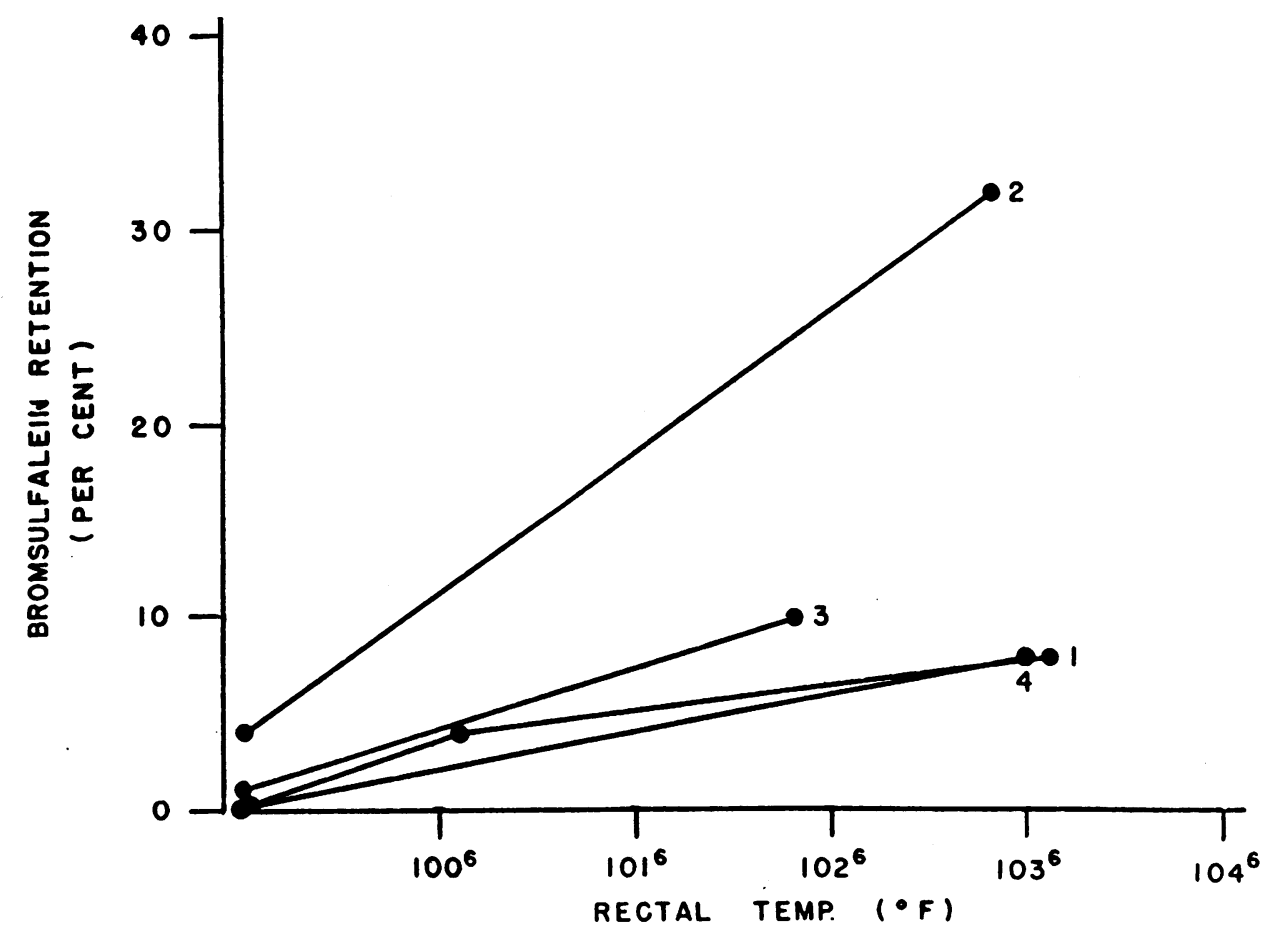

Fig. 5. Bromsulfalein Retention in Four Patients with Fever Induced by External Heat 
TABLE IV

Bromsulfalein tests at three-hour interval in ten patients with various disorders

\begin{tabular}{|c|c|c|c|c|}
\hline Subject & Diagnosis & Hour & $\begin{array}{l}\text { Rectal } \\
\text { temp. at } \\
\text { time of } \\
\text { test }\end{array}$ & $\begin{array}{l}\text { B.S.P. } \\
\text { retention }\end{array}$ \\
\hline \multirow{2}{*}{1} & \multirow{2}{*}{$\begin{array}{l}\text { Reiter's } \\
\text { syndrome }\end{array}$} & $8: 30$ & $\begin{array}{l}{ }^{\circ} \mathrm{F} . \\
99.0\end{array}$ & $\begin{array}{c}\text { per cent } \\
0\end{array}$ \\
\hline & & $11: 30$ & 99.8 & $\mathbf{0}$ \\
\hline \multirow{2}{*}{2} & \multirow{2}{*}{ C.N.S. syphilis } & $1: 50$ & 99.6 & 0 \\
\hline & & $4: 50$ & 99.0 & 0 \\
\hline \multirow{2}{*}{3} & \multirow{2}{*}{$\begin{array}{l}\text { Pernicious } \\
\text { anemia }\end{array}$} & $1: 45$ & 100.0 & 0 \\
\hline & & $4: 45$ & 99.6 & 0 \\
\hline \multirow{2}{*}{4} & \multirow{2}{*}{ C.N.S. syphilis } & $10: 00$ & 100.8 & 0 \\
\hline & & $1: 00$ & 100.4 & $\mathbf{0}$ \\
\hline \multirow{2}{*}{5} & \multirow{2}{*}{$\begin{array}{l}\text { Coronary } \\
\text { sclerosis }\end{array}$} & $8: 30$ & 99.4 & Trace \\
\hline & & $11: 30$ & 99.6 & Trace \\
\hline \multirow{2}{*}{6} & \multirow{2}{*}{$\begin{array}{c}\text { Bronchial } \\
\text { asthma }\end{array}$} & $1: 55$ & 99.6 & 2 \\
\hline & & $4: 55$ & 99.6 & 2 \\
\hline \multirow{2}{*}{7} & \multirow{2}{*}{$\begin{array}{l}\text { Ulcerative } \\
\text { colitis }\end{array}$} & $8: 40$ & 99.2 & 4 \\
\hline & & $11: 40$ & 99.0 & 4 \\
\hline \multirow{2}{*}{8} & \multirow{2}{*}{ Menorrhagia } & $10: 00$ & 99.6 & 4 \\
\hline & & $1: 00$ & 99.4 & 4 \\
\hline \multirow{2}{*}{9} & \multirow{2}{*}{$\begin{array}{l}\text { Primary } \\
\text { syphilis }\end{array}$} & $10: 00$ & 99.4 & 6 \\
\hline & & $1: 00$ & 99.8 & 5 \\
\hline \multirow{2}{*}{10} & \multirow{2}{*}{$\begin{array}{l}\text { Hyper- } \\
\text { thyroidism }\end{array}$} & $10: 00$ & 99.6 & 16 \\
\hline & & $1: 00$ & 100.2 & 14 \\
\hline
\end{tabular}

retention of the dye occurred after induction of fever.

3. It has been demonstrated that antipyretics in adequate dosage cause definite dissociation of the effects of foreign protein injection (32). The fever, chills, nausea and vomiting, and the initial blood pressure rise are deleted, while the induction of renal and hepatic hyperemia remains unaffected $(32,33)$. In view of this, eight subjects were given pyrogenic doses of foreign protein after they had received 0.6 grams of aminopyrine every four hours for at least 24 hours. The aminopyrine completely eliminated the expected chill and temperature rise. Bromsulfalein tests were performed before injection of foreign protein and repeated three hours later, when full effect of this injection would be expected. The results are shown in Table V. One subject showed an increase in bromsulfalein retention of 0 to $4 \%$ while in the other seven the results of the two tests were essentially the same.

\section{DISCUSSION}

It seems doubtful that non-specific fever alone is concerned in the production of positive cephalincholesterol flocculation tests in this series since positive tests were not observed in patients with induced fever and the incidence of positive tests in the malaria group was as high in afebrile patients as in those running a high fever. Furthermore, the incidence of positive tests in the convalescent non-febrile patients with atypical pneumonia was considerably higher than in the same patients while they were febrile. Moore, Hanger, et al. (34) have postulated that positive flocculation tests may be due to (1) increase in gamma globulin, (2) decrease in serum albumin or (3)

TABLE $V$

Bromsulfalein tests after foreign protein injection in eight patients receiving aminopyrine

\begin{tabular}{|c|c|c|c|c|}
\hline Subject & $\begin{array}{l}\text { Hours after } \\
\text { protein } \\
\text { injection }\end{array}$ & $\begin{array}{c}\text { Killed } \\
\text { typhoid } \\
\text { organisms }\end{array}$ & $\begin{array}{c}\text { Rectal } \\
\text { temp. at } \\
\text { time of test }\end{array}$ & $\begin{array}{l}\text { Brom- } \\
\text { sulfalein } \\
\text { retention }\end{array}$ \\
\hline \multirow{2}{*}{1} & & $\begin{array}{c}\text { millions } \\
0\end{array}$ & $\begin{array}{l}\circ \mathrm{F} . \\
99.0\end{array}$ & $\begin{array}{c}\text { per cent } \\
8\end{array}$ \\
\hline & 3 & 10 & 99.0 & 9.7 \\
\hline \multirow{2}{*}{2} & & 0 & 99.6 & 16.6 \\
\hline & 4 & 10 & 99.0 & 16.0 \\
\hline \multirow{2}{*}{3} & & 0 & 99.0 & 0 \\
\hline & 3 & 15 & 98.8 & 4 \\
\hline \multirow{2}{*}{4} & & 0 & 98.2 & 5 \\
\hline & 4 & 100 & 98.4 & 5 \\
\hline \multirow{2}{*}{5} & & 0 & 99.2 & 2 \\
\hline & 4 & 125 & 99.6 & 2 \\
\hline \multirow{2}{*}{6} & & 0 & 99.4 & 2 \\
\hline & 3 & 100. & 99.0 & 3 \\
\hline \multirow{2}{*}{7} & & 0 & 98.4 & 1 \\
\hline & 3 & 50 & 99.0 & 0 \\
\hline \multirow{2}{*}{8} & & 0 & 98.8 & 4 \\
\hline & 3 & 100 & 99.2 & 4 \\
\hline
\end{tabular}


decrease in the flocculation-inhibiting property of the albumin. Dole and Emerson (35) found that the gamma globulin was increased and the albumin was decreased in the electrophoretic pattern of patients with malaria. No electrophoretic studies of serum of patients convalescing from atypical pneumonia have been found, but it seems likely that an increase in gamma globulin occurs if immune bodies are formed. An increase in gamma globulin might explain the increasing percentage of positive flocculation tests observed during the convalescent phase.

Although the patients with various diseases showed abnormal BSP retention much more often on days when fever was present, the time that the test was performed did not necessarily coincide with the peak of temperature elevation. The results obtained with induced fever suggest that more detailed observation may have shown even better correlation between the temperature and dye retention.

The subjects who developed fever following foreign protein injection showed impaired ability of the liver to clear bromsulfalein. In patients with fever induced by the application of external heat, similar changes in clearance of the dye occurred. The administration of foreign protein which was not followed by temperature elevation, was not associated with impaired dye clearance. These results indicate that the fever rather than the foreign protein was the factor responsible for the dye retention. Since aminopyrine prevents the febrile response to foreign protein injection but does not prevent an increase in the blood flow to the kidney and liver, it appears probable that the diminished clearance of the dye observed in this study is due to impaired function of the cells in the liver rather than to changes in the hepatic circulation. The fact that in about one-half of the subjects with induced fever bromsulfalein clearance was impaired for 24 hours after fever subsided, favors this interpretation. In view of the jaundice and marked histologic change in the liver that has been reported after extreme hyperpyrexia (16-25) it appears probable that lower degrees of fever, such as encountered in this study, are associated with similar but less marked changes in the liver.
CONCLUSIONS

1. Abnormal bromsulfalein retention and abnormal cephalin-cholesterol flocculation tests occur frequently in disorders other than infectious hepatitis.

2. In a group of patients with atypical pneumonia, the highest incidence of abnormal cephalincholesterol flocculation reactions occurred during convalescence.

3. In all groups that were studied the incidence of abnormal bromsulfalein retention was much higher on days when fever was present.

4. Fever induced by artificial means was associated with diminished bromsulfalein clearance. For reasons presented in the discussion, it appears probable that diminished bromsulfalein clearance is due to impaired function of the cells in the liver.

5. The temperature of the patient at the time the test is performed must be considered in the interpretation of the bromsulfalein test.

\section{BIBLIOGRAPHY}

1. Kopp, I., and Soloman, H. C., Liver function in therapeutic malaria. Am. J. M. Sc., 1943, 205, 90.

2. Kern, R. A., and Norris, R. F., Liver involvement in malaria. U. S. Nav. Bull., 1944, 43, 847.

3. Guttman, S. A., Potter, H. R., Hanger, F. M., Moore, D. B., Pierson, P. S., and Moore, D. H., Significance of cephalin-cholesterol flocculation test in malarial fever. J. Clin. Invest., 1945, 24, 296.

4. Fredericks, M. G., and Hoffbauer, F. W., A study of the hepatic function in therapeutic malaria. J. A. M. A., 1945, 128, 495.

5. Lippincott, S. W., Ellerbrook, L. D., Hesselbrock, W. B., Gordon, H. H., Gottlieb, T., and Marble, A., Liver function tests in chronic relapsing vivax malaria. J. Clin. Invest., 1945, 24, 616.

6. Bronstein, L. H., and Reid, R. D., The cephalincholesterol flocculation test in malaria. Proc. Soc. Exper. Biol. \& Med., 1945, 60, 140.

7. Cook, C. D., and Hoffbauer, F. W., Liver functional impairment in therapeutic malaria with particular reference to the unsuccessful use of methionine as a protective agent. J. Lab. \& Clin. Med., 1946, $31,56$.

8. Glenn, P. M., Kaplan, L. I., Read, H. S., and Becker, F. T., Clinical and laboratory studies of liver function in therapeutic malaria. Am. J. M. Sc., 1946, 212, 197.

9. Lippincott, S. W., Marble, A. M., Ellerbrook, L. D., Hesselbrock, W. B., Egstrom, W. W., and Gordon, 
H. H., Liver function tests in neurosyphilitic patients with induced vivax malaria of Pacific and Mediterranean origin. J. Lab. \& Clin. Med., 1946, 31, 991.

10. Makari, J. G., The cephalin flocculation test in malaria. Brit. M. J., 1946, 1, 272.

11. Read, H. S., Kaplan, L. I., Becker, F. T., and Boyd, M. F., An analysis of complications encountered during therapeutic malaria. Ann. Int. Med., 1946, 24, 444.

12. Cohn, C., and Lidman, B. I., Hepatitis without jaundice in infectious mononucleosis. J. Clin. Invest., 1946, 25, 145.

13. Barker, M. H., Capps, R. B., and Allen, F. W., Acute infectious hepatitis in Mediterranean area. J. A. M. A., 1945, 128, 997.

14. Wade, L. J., and Richmann, E. E., The cephalincholesterol flocculation test. J. Lab. \& Clin. Med., 1945, 30, 6.

15. Machella, T. E., Relationship of bromsulphalein retention to the fever of natural $P$. falciparum malaria. Am. J. M. Sc., 1947, 213, 81.

16. Bragdon, J. H., The hepatitis of hyperthermia. New Eng. J. Med., 1947, 237, 765.

17. Warren, S. L., Scott, W.W., and Carpenter, C. M., Artificially induced fever for treatment of gonococcic infections in the male. J. A. M. A., 1937, 109, 1430.

18. King, A. J., Williams, D. I., and Nicol, C. S., Hyperthermia in treatment of resistant gonococcal and non-specific urethritis. Brit. J. Ven. Dis., 1943, 19, 141.

19. MacDonald, R. M., Toxic hepatitis in fever therapy. Canad. M. A. J., 1944, 51, 445.

20. Wilson, S. J., and Doan, C. A., Pathogenesis of hemorrhage in artificially induced fever. Proc. Soc. Exper. Biol. \& Med., 1939, 41, 115.

21. Chunn, G. D., and Kirkpatrick, C. L., Fatal result of artificial fever therapy; case report. Mil. Surgeon, 1937, 81, 281.

22. Wilbur, E. L., and Stevens, J. B., Morbid anatomic changes following artificial fever, with report of autopsies. South. M. J., 1937, 30, 286.
23. Schnabel, T. G., and Fetter, F., Fever therapy in gonorrheal arthritis and chorea. Ann. Int. Med., 1935, 9, 398.

24. Watts, F., and Hartman, F. W., Abstracts of Papers and Discussions, Fifth Annual Fever Conference, Dayton, Ohio. May, 1935.

25. Hartman, F. W., and Major, R. C., Pathological changes resulting from accurately controlled artificial fever. Am. J. Clin. Path., 1935, 5, 392.

26. Mateer, J. G., Baltz, J. I., Marion, D. F., and MacMillan, J. M., Liver function tests. J. A. M. A., 1943, 121, 723.

27. Hanger, F. M., Serological differentiation of obstructive from hepatogenous jaundice by flocculation of cephalin-cholesterol emulsions. J. Clin. Invest., 1939, 18, 261.

28. Quick, A. J., Clinical application of hippuric acid and prothrombin tests. Am. J. Clin. Path., 1940, 10, 222.

29. Phillips, R. A., van Slyke, D. D., Dole, V. P., Emerson, K., Hamilton, P. B., and Archibald, R. M., Copper sulfate method for measuring specific gravities of whole blood and plasma. Bull. U. S. Army M. Dept., 1943, 71, 66.

30. Thannhauser, S. J., and Andersen, E., Bilirubin in blood serum. Deutsches Arch. f. klin. Med., 1921, 137, 179.

31. Evelyn, K. A., and Malloy, H. T., Microdetermination of oxyhemoglobin, methemoglobin, and sulfhemoglobin in single sample of blood. J. Biol. Chem., 1938, 126, 655.

32. Smith, H. W., Physiology of Renal Circulation. Harvey Lectures, 1939-1940, 35, 166.

33. Bradley, S. E., and Conan, N. J., Estimated hepatic blood flow and bromsulfalein extraction in normal man during the pyrogenic reaction. J. Clin. Invest., 1947, 26, 1175 (abstract).

34. Moore, D. B., Pierson, P. S., Hanger, F. M., and Moore, D. H., Mechanism of the positive cephalincholesterol flocculation reaction in hepatitis. J. Clin. Invest., 1945, 24, 292.

35. Dole, V. P., and Emerson, K., Jr., Electrophoretic changes in plasma protein patterns of patients with relapsing malaria. J. Clin. Invest., 1945, 24, 644. 